Carlos Leite

PhD, Associate Professor

Mackenzie Presbiterian University, São Paulo, Brazil

Vicente del Rio

$\mathrm{PhD}$, Associate Professor

Karlo Felix

BSCRP Student

City and Regional Planning Department

Cal Poly San Luis Obispo

\section{Sustainable Redevelopment and Innovation In a Global City Interdisciplinary Design for São Paulo, Brazil}

In the Fall of 2004, CRP had visiting scholar Carlos Leite for post-doctoral studies, research and teaching. He offered a course where students from city and regional planning, landscape architecture, and architecture, were able to study São Paulo, a global city with a population of 18 million people. Students were challenged into innovative projects for the sustainable redevelopment of a railroad brownfield in the high-density central city as an opportunity for positive territorial and social transformations.

One of the most important pedagogies in environmental design education is the stimulation of cross-fertilization between disciplines, individual and team work, students and teachers, practice and theory, in-depth research and pragmatic contributions from practitioners. Seminars and studios that allow for debate on and experimentation with contemporary urban design are rare and enriching opportunities. Given this pedagogical concerns, the metropolis of São Paulo in Brazil, is a perfect urban setting for experimental and interdisciplinary studies. With a population over 18 million and in a state of constant transformations, post-industrial São Paulo reflects well the complexity of contemporary design and its importance as a tool for joining the fragmented metropolis and generate positive transformations.

\section{THE STUDIO: RESEARCH AND PRACTICE IN URBAN DESIGN}

The opportunity of having professor Carlos Leite visiting for the fall quarter allowed CRP to offer a special joint seminarstudio course for students in the college. This interdisciplinary endeavor attracted 14 students: five undergrads and two grads from CRP, three undergrads from LA, and four undergrads from Arch - three of which were French exchange students. The course was a combination of advanced seminar and studio for the study of sustainable redevelopment in global cities of developing countries. This combination was essentially interdisciplinary and exploratory, relying on the examination of innovative and advanced design issues, and on critical thinking.

Model of a post-industrial metropolis that is constantly mutating and reflecting changes from both the local and global economies, São Paulo was the perfect case study. It is the largest and most important city for the Brazilian economy, ranking as one of the world's five largest metropolises. Transformations in its dense and chaotic urban structure leave a large number of blighted, residual, and ill-defined spaces, particularly in the central areas where they disarticulate the urban tissue, impede movements, and prevent integrated development. If correctly tackled with a comprehensive strategy for sustainable redevelopment, these areas may be regarded as excellent opportunities for positive territorial and social transformations.

Because present metropolitan problems -from São Paulo and Tokyo to Los Angeles- do not distinguish the scale of the design solution, the studio also experimented in

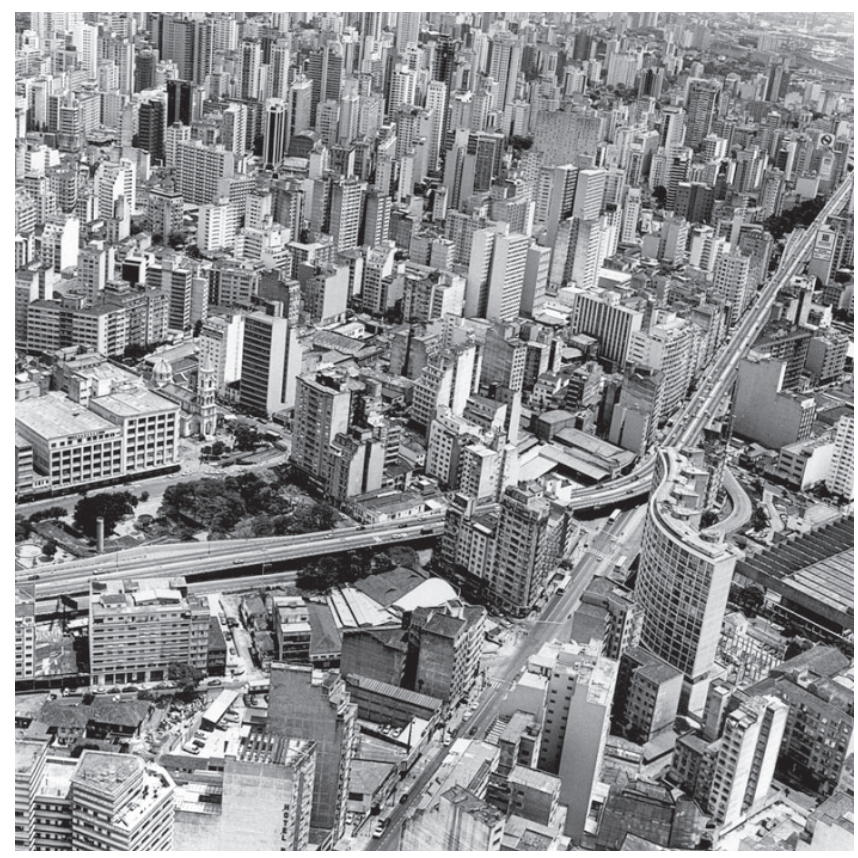

Figure 1. View of downtown Sao Paulo. 


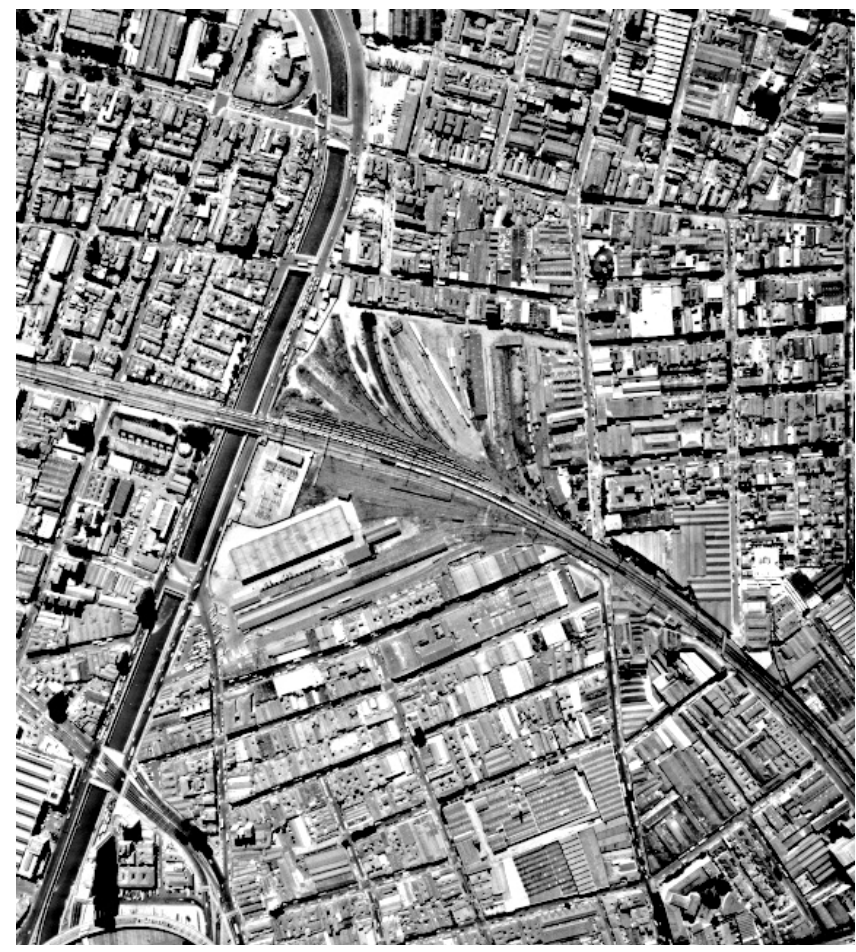

Figure 2. Project site in São Paulo.

dealing with the problems at multiple levels. An approach and an operational scale that may be called "architectural urbanism", which allowed students to bridge the realms of planning, landscape architecture, and architecture. The class faced multi-dimensional problems with innovative urban catalysts-such as higher density mixed-uses, multi-nodal traffic centers, clusters and technopoles- and opportunities for sustainable redevelopment of the city within in the global network.

\section{PROGRESSION OF THE COURSE}

At the start of the course, the concepts of sustainable redevelopment, city innovation, global city-regions, and productive urban restructuring were studied and discussed. Then, by looking at contrasting organizational structures, the class concentrated in the changing attitudes and cultural biases toward "top-down" and "ground-up" planning and implementation strategies. The examination of case studies and significant urban projects allowed the class to understand the cultural, political, and economical forces behind these projects, and the conflicts between plan and implementation. Boston's Route 128, Silicon Valley, San Francisco Mission Bay, and Montreal's Multimedia City were taken as case studies by the class, and the presentations by the instructor were followed by in-depth discussions led by the students based on their readings, studies, and findings.

For the design work, the class was divided into three interdisciplinary teams who developed their own strategies and conceptual projects for the redevelopment of a specific site in central São Paulo, for which the instructor had brought all the background readings and materials, including census and city data and Autocad files. The site is an abandoned railroad yard located in the banks of a canalized river, sitting alongside a busy expressway and an old industrial neighborhood. Students had to come up with projects to reconnect the site to the remainder of the city fabric through planning solutions and design ideas that were innovative and socially, economically, and environmentally sustainable.

This represented a huge challenge for students who not only were given a very complex design theme, but one which political, economic, and cultural frameworks were so different from what they were used to. They had to struggle in a little known developmental scenario as if they were facing a real fast international consulting job! The three interdisciplinary student teams developed very different and quite innovative approaches reflecting their different personalities and the leading disciplinary backgrounds, which resulted in interesting -and intriguing- design solutions.

\section{TEAM 1: NOAH CHRISTMAN AND SARA ALBANO (CRP); MEGAN BLENCOWE (LA), AND BILL BRADFIELD (ARCH)}

The group envisioned a monumental display for the site, harnessing the influence of technology and the adjacent river to create a development unlike any other in the city. The design was an amalgamation of five main ideas that were produced throughout the course. The first was the concept of a mixed-use spine running the length of the project area, where residential and commercial uses become both a connector and a destination. The second concept provided a pedestrian refuge above the northbound lanes of Avenida do Estado expressway and allowed a connection with the surrounding city. The shopping bridge, perched approximately seven meters above the asphalt, is linked across the river via 


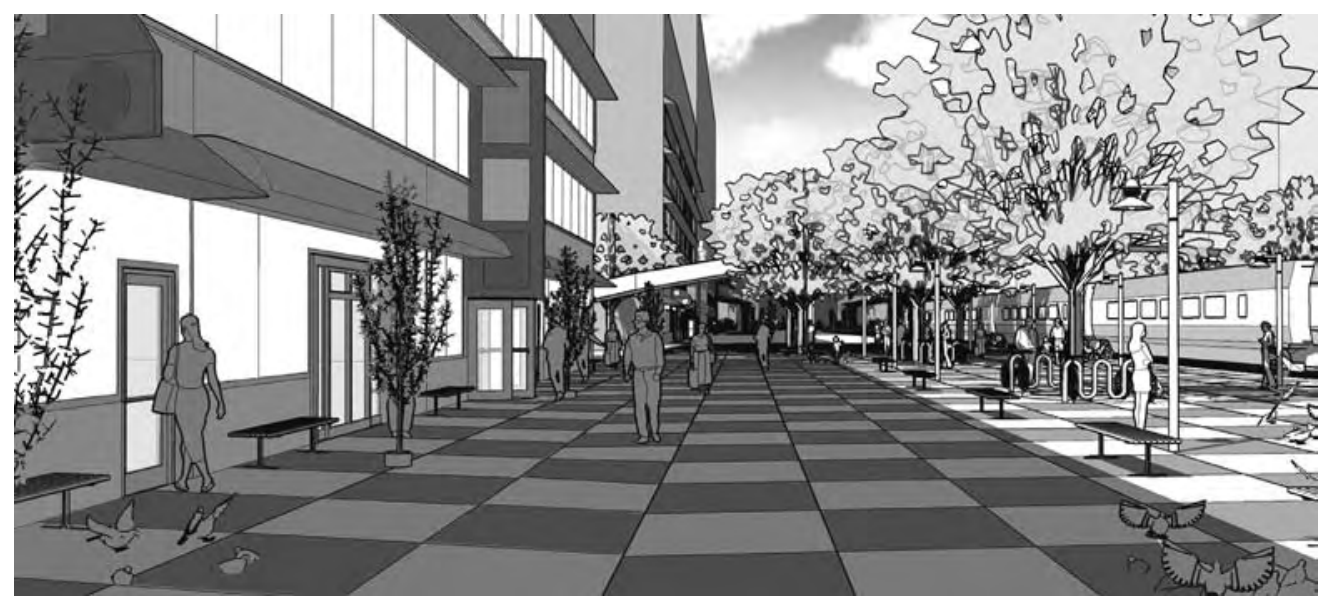

Figure 3. Computer simulation of the mixed-use corridor in Team 1's proposal.

pedestrian footbridges and to the site itself with an extension of the spine concept.

Another of the team's concepts was to have a technopole as an economic catalyst to help revitalize the area. As flooding of the adjacent river poses a significant problem, the fourth site concept expanded the flood control idea to include a permanent water feature on the site: cutting a swath through the site area and allowing for the river path to fill it naturally would not only provide greater surface area to discourage flooding, but also create an aesthetically pleasing element for pedestrians. The final main concept was to implement a system of green corridors on the site that could also be used for pedestrian circulation. The team also proposed lay-outs for innovative "green" high-density apartment towers with floor plans that allowed for "vertical gardens", and blocks with low density housing that followed American "new urbanist" principles.

\section{TEAM 2: KARLO FELIX, ERIC CROW, AND ANDREA LARSEN (CRP), INGRID STROMBERG AND MATHEW TAYLOR (LA)}

Nicknamed the "planning group" because of their composition and approach, this pragmatic group compensated the lack of more thorough theoretical discussions with developing a number of alternative planning and design strategies. When facing a "turning point" near the end of the term the group took the courageous decision to propose something very different and innovative: their design would reveal the site's territorial transformations through the building typologies and urban artifacts.
Through the interplay of solids and voids, this new urban structure would reflect an "archeological undereading" of the old forgotten railroad tracks. New buildings would stand out as "positive spaces" and stress the "negative space" of open areas and parks which double as flood plains. A tree-lined paseo cuts through the built form and offers a stark contrast as unifying element. The group also made the important decision to locate a new public transit facility at the center of the project, and incorporated current city plans for a monorail along the river and a light-rail along the existing tracks. The project's territorial inscriptions signalize and indicate the way the new high-dense urban design occurs.

\section{TEAM 3: EUGENIE BLATT, ANNE CLAIS, AND ANISSA KADA (ARCH), ANDY BURSAN AND NATHAN GILBERT (GRAD CRP)}

This group, constituted by three French students participating in the exchange program with the Architecture Department and two graduate students from CRP, was the most conceptual. Their effort reflected the French tradition of critical thinking and theoretical inventions, which unfortunately left them with little time to develop the specifics for their response to the site.

Nevertheless, these "thinkers/writers" driving idea was that the intervention should generate a "territory of silence" through a single and strong linear gesture on the existing wasteland. An elevated esplanade would cut through the entire site holding an entertainment center with retail, restaurants, bars, and nightclubs. The rest of the area was to be maintained "unbuilt" with a landscape design dedicated to 
recreational uses and which vegetation would be treated with different densities: from a forest buffer along the river to a grid with different densities towards the middle of the area.

\section{CONCLUSION}

The end results of this experimental interdisciplinary seminarstudio were extremely positive, and this was an excellent opportunity to expand CAED's reach. Students responded very well to a challenge that was totally new for them, as few had any notion of a city as dense and as complicated as São Paulo, and they were not used to looking into a complex situation through a multi-level approach. This studio and its design products represent well Cal Poly's "learn-by-doing" pedagogy, and also opened new professional roads for students interested in international development.

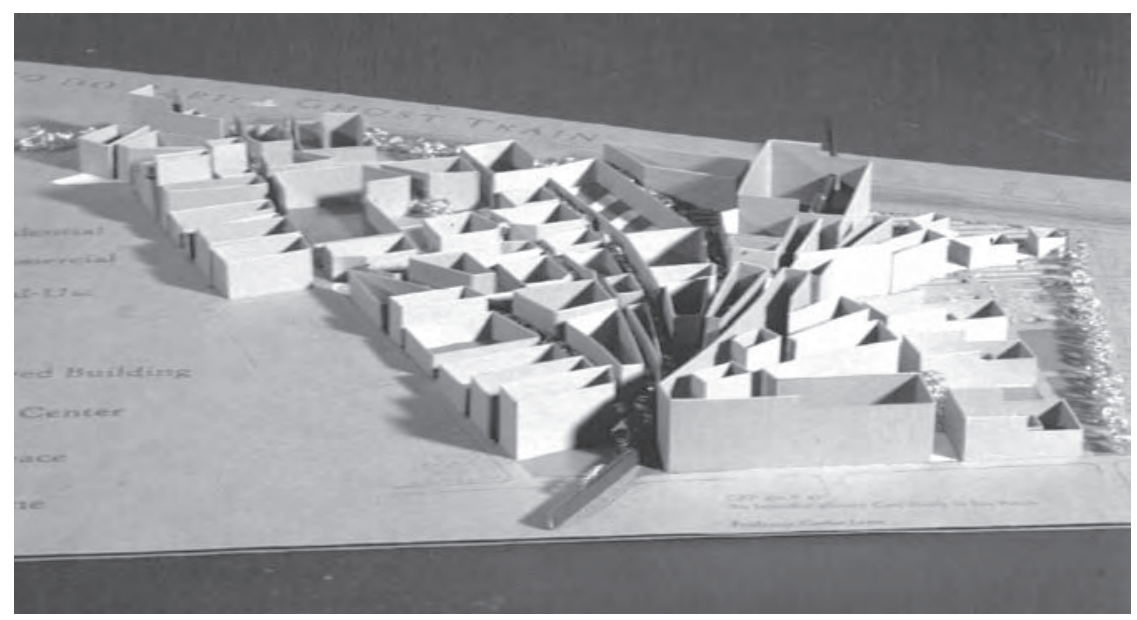

Figure 4. Model from Team 2 showing how the volumes insinuate the old railroad tracks.



Figure 5. The group with profesor Leite 